\title{
National Marrow Donor Program
}

National Cancer Institute

\section{Source}

National Cancer Institute. National Marrow Donor Program. NCI Thesaurus. Code C62593.

A non-profit organization based in Minneapolis, MN, that facilitates hematopoietic cell transplants and cellular therapies for patients by connecting patients, doctors, donors and researchers to the resources they need. 